\title{
Is increased agricultural protection beneficial for South Africa?
}

\author{
Ramos Mabugu $^{\mathrm{a} *}$, Margaret Chitiga ${ }^{\mathrm{b}}$ \\ ${ }^{\text {a }}$ Financial and Fiscal Commission, Midrand, SouthAfrica \\ ${ }^{\mathrm{b}}$ DepartmentofEconomics, University of Pretoria,South Africa
}

\begin{abstract}
A B S T R A C T
Using a top down computable general equilibrium microsimulation model of South Africa, this paper explores the impact on household well being of an increase in agricultural protection. This issue is of broader relevance to developing countries that may be contemplating the use of World Trade Organisation permissible trade barriers so as to achieve a domestic policy objective. The model predicts that gross domestic product would be unaffected while real private consumption falls. The real exchange rate appreciates while unemployment levels are unaffected. Food, other manufactures, trade and hotels are the clear losers. All other industries experience small positive gains or no impact on their output. The impact on households depends on their factor endowments and their consumption patterns. The impacts on poverty reduction are very small. Poverty indicators increase more in urban areas than in rural areas. Poverty increases slightly more among Asian households, followed by White and then Coloured households. African households experience small declines in poverty.
\end{abstract}

Keywords:

CGE model; Microsimulation; Agricultural trade policy; Special and differential treatment ; Poverty; Welfare; South Africa

\section{Introduction}

There have been a number of calls made recently by Agriculture South Africa and Grain South Africa on the government to increase agricultural tariffs in order to prevent domestic agriculture from collapsing due to loss of domestic market share to competitors from abroad. South Africa's applied agricultural tariffs are in many cases well below the bound rates and could be increased without violating the country's World Trade Organisation (WTO) commitment. Vink and Tregurtha (2003) have shown that South Africa has a lot of room to manoeuvre in the Special and Differential Treatment (SDT) provisions of the WTO if it wants to protect local producers. Although the chances that South African agriculture could enjoy substantial protection in the current open trade policy regime are very slim, the question of WTO permissible protection increases is important because of at least two reasons. First, it presents an interesting case of how a country might use WTO permissible trade barriers in order to better achieve a domestic policy objective. Second, the issue is of broader relevance to developing countries that may be contemplating the use of SDT provisions so as to better achieve their developmental objectives from multilateral trade reforms. This issue is at the heart of current negotiations within the Doha Development Agenda (DDA) (DiazBonilla et al., 2003; Konandreas, 2003).

The aim of this paper is to contribute to this debate by exploring the effects that higher protection for agriculture could have on efficiency, sectoral performance, welfare, and poverty in South Africa. Standard neoclassical trade theory would predict an overall welfare loss from the unilateral imposition of a selective tariff by a small open economy such as South Africa. This is because such policies do in fact impose a distortion. Furthermore, proponents of such policies rarely give consideration to the impacts on other sectors of the economy and on social outcomes such as poverty that may be set in motion by such interventions. The focus on poverty in this paper is appropriate because of the high and rising poverty levels in South Africa (Hoogeveen and Ozler, 2004). ${ }^{1}$ Indeed, the South African government has recently identified poverty alleviation as an important target of its development programmes.

To assess the general equilibrium efficiency and welfare effects of increased agricultural protection, we make use of a computable general equilibrium (CGE) model for South Africa. We follow the top down approach and use a nationally representative household survey to estimate the poverty and inequality effects of the shock. To model higher protection of agriculture, we double the import tariffs on this sector. We have therefore implicitly assumed that protectionist political pressures are sector specific so that we could analyse what would happen if this sector succeeds in obtaining protection, with no other changes in trade policy.

The rest of the paper is structured as follows. Section 2 gives a brief review of agriculture and trade in South Africa. In Section 3 the model and data are discussed. Section 4 gives a discussion of the scenarios analysed, followed by a discussion of the results. Section 5 concludes the paper. 
Table 1

SACU applied ad valorem duties on selected products

\begin{tabular}{llll}
\hline & SADC & EU & Rest of the world \\
\hline Boneless beef & $32 \%$ & $40 \%$ & $40 \%$ \\
Powdered milk & $360 \mathrm{c} / \mathrm{kg}$ & $450 \mathrm{c} / \mathrm{kg}$ & $450 \mathrm{c} / \mathrm{kg}$ \\
Wheat grain & $16.4 \mathrm{c} / \mathrm{kg}$ & $19.6 \mathrm{c} / \mathrm{kg}$ & $19.6 \mathrm{c} / \mathrm{kg}$ \\
Wheat flour & $20 \%$ & $20 \%+29.4 \mathrm{c} / \mathrm{kg}$ & $20 \%+29.4 \mathrm{c} / \mathrm{kg}$ \\
Maize grain & $6.7 \mathrm{c} / \mathrm{kg}$ & $6.7 \mathrm{c} / \mathrm{kg}$ & $6.7 \mathrm{c} / \mathrm{kg}$ \\
Maize flour & $10.1 \mathrm{c} / \mathrm{kg}$ & $10.1 \mathrm{c} / \mathrm{kg}$ & $10.1 \mathrm{c} / \mathrm{kg}$ \\
Frozen chicken & $22 \%$ & $27 \%$ & $27 \%$ \\
Lamb/mutton & $32 \%$ & $40 \%$ & $40 \%$ \\
Cut flowers & $13 \%$ & $15 \%$ & $20 \%$ \\
Oranges & Free & $3.70 \%$ & $5 \%$ \\
Apples & Free & $3.70 \%$ & $5 \%$ \\
Onions & Free & $11.20 \%$ & $15 \%$ \\
Tomatoes & Free & $11.20 \%$ & $15 \%$ \\
Cane sugar & $66.6 \mathrm{c} / \mathrm{kg}$ & $66.6 \mathrm{c} / \mathrm{kg}$ & $66.6 \mathrm{c} / \mathrm{kg}$ \\
\hline
\end{tabular}

Source: Kandiero et al. (2004).

Note: c stands for South African cents. 100 cents make up 1 South African Rand.

\section{Trade policy and agriculture in South Africa}

South Africa's agro-food trade regime has been historically characterized by quantitative restrictions, many tariff lines with a wide distribution and a host of other forms of protection such as formulae, specific and ad valorem duties and surcharges. A decision to phase out the General Export Incentive System (GE1S) that was considered to be inconsistent with General Agreement on Trade and Tariffs (GATT) and the World Trade Organisation (WTO) rules was reached in 1994. They were eventually terminated in $1997 .{ }^{2}$ In that settlement, the country agreed binding $98 \%$ of all tariff lines. As well, the deal involved reducing the number of tariff lines to six, rationalising the twelve thousand commodity lines and replacement of quantitative restrictions on agriculture by tariff equivalents (Kirsten and Vink, 2002). South Africa has made a lot of progress towards meeting its international trade commitments, reforming and simplifying its tariff structure. As far as the agro-food sector is concerned, there has been a noticeable decline of tariff lines as well as tariff levels. Agricultural tariff levels have fallen by $38 \%$. The protection of agricultural and food products is now based largely on specific and ad valorem tariffs. There are also tariff rate equivalents that apply to products and certain countries, anti-dumping and countervailing duties. Besides tariff barriers, quotas, licences, import permits, different sanitary and phyto-sanitary (SPS) measures, quality standards as well as rules of origin still apply to some degree in agriculture.

Trade policy in South Africa is not only driven by multilateral arrangements but also by bilateral and regional agreements. The Southern African Customs Union (SACU) between South Africa, Botswana, Lesotho, Namibia, and Swaziland (BLNS) is the oldest Customs Union in the world. South Africa's agricultural tariffs are guided by the SACU common external tariff. Average duty is at $9.7 \%$ which is below the commitment level of bound rates at $39.7 \%$.

There are two significant Free Trade Areas (FTAs) that the country has so far concluded, namely the European Union (EU) - South Africa FTA (agreed in 1999) and the Southern Africa Development Corporation (SADC) FTA (implemented in September 2000). Current tariffs provide preferential treatment to SADC countries while the rest of the world and the EU pay higher import duties (Table 1). Relatively low applied tariffs for agricultural imports from non SACU/SADC countries are intended to contribute towards regional integration in accordance with the SADC Trade Protocol of 2000. Table 1 shows applied ad valorem duties for selected agricultural products.

According to Organisation for Economic Co-operation and Development (2006), maize has a specific duty that is calculated using a formula based on world prices and relevant exchange rates. Between 1998 and 2005, the ad valorem equivalent of the duty has varied between 0 and 28\%. Similar arrangements for wheat applied until 2005 and the duty ranged between 0 to 30\%. Commencing in July 2005, the formulae for wheat was replaced by an ad valorem duty of $2 \%$. Sugar and products have equivalent ad valorem rates that range between 0 and $25 \%$. However, there is an additional duty level adjustment that is based on a trigger price system. This has had the effect of raising ad valorem rates to between 12 and $85 \%$ between 2001 and $2005 .^{3}$ 
Table 2

South African agricultural exports and imports (2002-2004 average)

\begin{tabular}{lll}
\hline & Exports & Imports \\
\hline Europe & 47 & 22 \\
Africa & 26 & 10 \\
Asia & 18 & 26 \\
America and Canada & 7 & 11 \\
Latin America & 1 & 24 \\
Oceania & 1 & 7 \\
\hline
\end{tabular}

Source: Organisation for Economic Co-operation and Development (2006).

Table 2 shows the geographical distribution of agro-food imports and exports. Europe (particularly European Union 15) is by far the largest destination for South African exports (47\%), followed by Africa (26\%), Asia (18\%) and then United States of America and Canada (7\%). Latin America and Oceania are insignificant destinations for South African imports, accounting for about $1 \%$ of market share each. There are a variety of products that are exported with wine, fresh and processed fruits and sugar together accounting for over $51 \%$ of exports.

When focusing on agro-food imports, we notice that there is no single region that dominates. Rather, Asia, Latin America and Europe account for the bulk of the imports. It is noticeable that Latin America and Oceania become important sources of imports while they were insignificant export destinations. On the other hand, Africa is an insignificant source of agricultural imports while it was an important destination for exports. The main imported items are oils and oilseeds, grains, cotton and tobacco. The major imported agricultural products are soybean/soybean oil, rice and wheat.

\section{The CGE microsimulation model and data}

A CGE model is used to construct a reference equilibrium against which the effects of increased agricultural protection can be quantified and evaluated. There is a growing tradition of CGE modeling focused on analyzing trade issues in South Africa. Useful reviews of CGE models used in South Africa can be found in Thurlow and van Seventer (2002), Woolard and Wilson (2004) and McDonald and Punt (2005). The CGE work is predominantly focused on trade and macroeconomic policy analysis based on representative household groups. Although, the representative household model gives interesting insights on the average impacts on household groups, it cannot capture the substantial heterogeneity among households within a given group as CGE micro-simulation models do. Therefore, this study considers all actual households from the national income and expenditure survey of South Africa to assess the impact of increased agriculture and food protection on household poverty and welfare. ${ }^{4}$ The rest of this section discusses the CGE model, the microsimulation model and the data used to implement the models.

\subsection{The CGE model}

The study uses a South African model with a rest-of-the-world link through export and import flows (Decaluwe et al., 2001). In line with other trade focused CGE models, a main feature of the model is the modelling of two way trade in the same commodity by way of the Armington assumption of less than perfect substitution between domestic goods and traded goods. The production side is characterized by a multi level nested production structure that utilises intero-mediate inputs and primary factors of production. Sectoral output is modelled using a Leontief production function with value added and intermediate inputs. Domestic intermediate deliveries are also modelled using sectoral Leontief coefficients. On the other hand, value added is modelled as a constant elasticity of substitution (CES) of capital, land and labour. Domestic production and exports are combined using a constant elasticity of transformation (CET) function to form an output composite. This imperfect substitution captures any time or quality differences between the two products.

Taking into account South Africa's historical apartheid legacy and the importance of ethnicity, this study distinguishes four categories of households with quite different sources of income and consumption (African, Coloured, Asian and White) which are consistent with government categorisation of races. It is assumed that the labour market is segmented. Workers are distinguished into high-skilled and low-skilled categories and into their ethnic group. ${ }^{5}$ There is unemployment of unskilled labour while skilled labour is a scarce factor. We use the fixed real wage (but changing nominal wage) and unemployment for low skilled workers and flexible wage rates with full employment for high skilled workers. ${ }^{6}$ Labour supply is exogenous in the model. Allowing the supply of labour to be endogenously determined 
by households is not relevant in our study as we have a short term perspective. Thus, new educated labour and/or high skilled labour migrants will not play an important role in the model. With the presence of unemployment rationed on the demand side, high (low) employment will lead to low (high) participation to economic activity and will not necessary impact on the low skilled wage rates assumed fixed in real terms.

High skilled and low skilled workers are immobile between urban and rural areas as we do not focus on the rural and urban migration issue in this study. Workers are immobile between urban and rural areas according to the short term perspective of the analysis and the absence of explicit treatment of migration between the two areas. High-skilled workers do not compete for low-skilled jobs and low skilled workers similarly do not compete for high skilled jobs. As a result, high-skilled and low-skilled workers in both urban and rural areas participate in different labour markets. Each category of labour is assumed to be perfectly mobile across industries. Given the short term perspective of this study, it is assumed that the employment decisions in general public administration are exogenously determined as government hiring possibilities are limited. Therefore, fixed indexed-wage rates prevail in the general government services, while other industries take the market wage rates as given.

General equilibrium requires that the goods and factor markets are in equilibrium and that the fundamental macroeconomic identity is satisfied. All commodity markets follow the neoclassical market-clearing price system, in which jointly determined producer and consumer prices vary only by given tax, subsidy and margins rates. The foreign exchange market equilibrates via adjustments of the real exchange rate. Pressures to change export or import quantities (and hence, demand and supply of foreign currency) are equilibrated by adjustments in the real exchange rate. Real investment is fixed at the base year value so as to avoid getting favourable welfare effects even when investment is falling. In line with most welfare analysis in public finance, public savings are made exogenous so as to avoid analyzing the welfare impacts of government spending. The revenue that is sufficient to attain the given level of government spending can be reached through adjustment of direct taxes on household income or indirect taxes. Foreign savings are fixed in order to avoid both a "free lunch" situation as well as analyzing dynamic debt issues. Households adjust their savings endogenously until the savings — investment balance is attained. This specification allows insights into the 'true' static welfare effects of increased agricultural protection as well as the importance of alternative revenue compensation measures put in place.

The model is homogenous of degree one in all prices and nominal values. Our "numeraire" is the global producer price index at its initial level, and all nominal values are thus measured in real terms relative to this price. Fixed wages in this context should be interpreted in terms of production cost. Real incomes are computed with social group-specific consumer price indices which, unlike the global producer price index, include the prices of imported goods, taxes, and subsidies. The model solves for one-period equilibrium and results have to be interpreted in comparative static terms.

\subsection{Poverty analysis}

To carry out poverty and inequality analysis, the top down micro-simulation approach is used. This procedure involves first obtaining post simulation results of consumer prices and household consumption from the CGE model. In a second step, these results are applied to the benchmark data drawn from a nationally representative household survey in order to analyse poverty effects. Post protection consumption data are deflated by the Laspeyres economy-wide consumer price index to account for the change in the general price-level. The poverty line used is the lower bound estimate of 3864 South Africa rands per year in 2000 prices suggested by Hoogeveen and Ozler (2004). The well known Foster-Greene-Thorbecke (FGT) poverty indicators (that is, head count, poverty gap, and squared poverty gap) are used for poverty analysis (Foster et al., 1984)7 The FGT index is:

$$
P(z ; \alpha)=\int_{0}^{1} g(p, z)^{\alpha} d p
$$

where $\alpha \geq 0, z$ is the poverty line. When $\alpha=0$, the FGT index indicates the proportion $P_{0}$ of the poor. The FGT indexes are decomposable, and this helps us to analyse the contributions of different groups of households to global poverty. The contribution of each socio economic group to global poverty is given by:

$$
q=K_{j} p_{X j} / p_{a}
$$

where $P_{x}$ is the poverty index for group $j, K j$ the proportion of the population in group $j$. This knowledge of the groups' contributions in the total index is useful for formulating more precise economic policies towards vulnerable groups. While micro-macro consistency equations, along with the direct transmission of prices ensure that macrochanges are fully transmitted to the microsimulation model, it is important to realize that the sequential procedure employed does not allow for a feedback of effects from the microsimulation model back to the macroeconomy. This would require a fully integrated CGE microsimulation model. 
Table 3

Average protection and sectoral shares

\begin{tabular}{|c|c|c|c|c|c|c|}
\hline \multirow[t]{3}{*}{ Industry } & \multirow[t]{3}{*}{ Import tariff } & \multicolumn{5}{|l|}{ Sectoral shares of } \\
\hline & & \multirow{2}{*}{$\frac{\text { Value added in }}{\text { Total value added }}$} & \multirow{2}{*}{$\frac{\text { Imports in }}{\text { Total imports }}$} & \multirow{2}{*}{$\frac{\text { Exports in }}{\text { Total exports }}$} & \multirow{2}{*}{$\frac{\text { Imports in }}{\text { Armington good }}$} & \multirow{2}{*}{$\begin{array}{l}\text { Exports in } \\
\text { Gross supply }\end{array}$} \\
\hline & & & & & & \\
\hline Agriculture & 0.6 & 3.6 & 1.9 & 4.4 & 6.7 & 15.6 \\
\hline Coal & 0.0 & 1.4 & 0.3 & 5.3 & 5.7 & 50.5 \\
\hline Gold & 0.0 & 2.4 & 0.0 & 14.7 & 0.0 & 92.8 \\
\hline Other mining & 0.0 & 2.6 & 7.1 & 16.0 & 62.4 & 79.9 \\
\hline Food & 7.0 & 3.4 & 4.4 & 5.1 & 5.6 & 7.8 \\
\hline Textiles & 8.7 & 1.0 & 2.9 & 2.0 & 11.9 & 10.0 \\
\hline Footwear & 26.4 & 0.1 & 0.8 & 0.1 & 18.7 & 3.1 \\
\hline Petroleum & 5.2 & 4.1 & 14.4 & 9.4 & 17.4 & 14.8 \\
\hline Non metallic mineral products & 15.0 & 0.7 & 1.1 & 0.8 & 13.4 & 10.5 \\
\hline Basic iron and steel & 2.3 & 4.3 & 22.2 & 19.0 & 32.2 & 31.4 \\
\hline Electrical machinery & 10.6 & 0.6 & 2.8 & 1.0 & 23.5 & 11.7 \\
\hline Radio & 3.4 & 0.3 & 8.7 & 0.9 & 51.4 & 12.0 \\
\hline Transport equipment & 4.8 & 1.4 & 14.7 & 4.7 & 33.1 & 15.6 \\
\hline Other manufacturing & 6.7 & 3.2 & 6.6 & 7.7 & 15.2 & 18.9 \\
\hline Electricity & 0.0 & 2.8 & 0.0 & 0.2 & 0.0 & 1.6 \\
\hline Water & 0.0 & 0.5 & 0.0 & 0.0 & 0.1 & 0.0 \\
\hline Construction & 0.0 & 3.2 & 0.2 & 0.0 & 0.6 & 0.1 \\
\hline Trade & 0.0 & 12.3 & 0.1 & 0.1 & 0.1 & 0.1 \\
\hline Hotels and restaurants & 0.0 & 2.1 & 1.4 & 1.7 & 10.6 & 13.6 \\
\hline Transport services & 0.0 & 5.2 & 6.8 & 3.4 & 16.1 & 9.2 \\
\hline Communications & 0.0 & 3.2 & 1.1 & 0.6 & 4.9 & 3.1 \\
\hline Financial intermediation & 0.0 & 8.7 & 1.1 & 1.9 & 1.9 & 3.5 \\
\hline Real estate & 0.0 & 6.7 & 0.1 & 0.0 & 0.3 & 0.1 \\
\hline Business activities & 0.0 & 2.9 & 0.7 & 0.4 & 3.5 & 1.9 \\
\hline General government & 0.0 & 17.4 & 0.0 & 0.0 & 0.0 & 0.0 \\
\hline Health and social work & 0.0 & 1.8 & 0.1 & 0.1 & 0.4 & 0.6 \\
\hline Other activities and services & 0.0 & 4.0 & 0.7 & 0.4 & 2.6 & 1.6 \\
\hline ALL. & 3.9 & 100.0 & 100.0 & 100.0 & 12.3 & 13.7 \\
\hline
\end{tabular}

${ }^{7}$ Some examples are FGT index, Watts's index, and Clark, Hemming and Ulph (CHU) index.

\subsection{The data}

Three sets of data are required to run the microsimulation model just described. These are the Social Accounting Matrix (SAM), behavioural data (elasticities) and household level consumption/income data (for microsimulation). Below is a discussion of these various data for the South African model.

\subsubsection{The SAM}

The SAM distinguishes 28 productive sectors (activities) and the 28 commodities that they produce. There is a single account for agriculture and this introduces inherent biases of aggregation. ${ }^{8}$ The trade transactions recorded in the database do not distinguish between commodities on the basis of their regions of origin and destination but on the basis of the agents including intermediate demand and final demand by household, government, investment and the rest of the world. This is important because the primary interest in this paper is with the national repercussions of increased protection in all agriculture sectors, rather than the global effects.

Table 3 shows that the economywide tariff rate is relatively low at 3.93\%, implying low protection overall. A main drawback of using average tariffs as a measure of protection is that tariff rate quotas are not modelled and this may increase inherent biases especially given the various FTAs and preferences that exist. While the economywide tariff is relatively low, this masks significant sectoral variation that highly distorts the trade regime. Tariffs are in general low in agriculture and fairly moderate for the industrial sectors. Agriculture faces an average protection of $0.64 \%$. There are high tariffs for sectors such as footwear, other non-metallic mineral products, electric machinery, textiles and food. As imported food and agriculture products are fairly close substitutes for domestic food and agricultural products, food and agriculture imports should fall considerably under increased protection. The food sector also has one of the highest domestic indirect taxes, along with petroleum, radio, real estate and transport equipment.

Table 3 also shows the trade orientation of the economy. Manufacturing and mining are the most dominant sectors as far as exports are concerned, contributing about $82 \%$ to total exports between them. Imports are dominated by manufactures, making up 74\% of total imports. Food and agriculture are fairly important exporters, making up about $9 \%$ of exports taken together. The food and agricultural sectors are small importers compared to the total, with agriculture making up about $1.9 \%$ and food a further $4.4 \%$ of total imports. According to the export 
intensity measure, mining is by far the most export intense sector. Using this same measure, agriculture and food have quite high export intensities relative to other sectors in the economy.

The measure of import penetration in Table 3 gives a sense of the contestability of domestic production by imports. Mining, which is the dominant sector in terms of exports contribution, is also highly vulnerable to import competition, with an import penetration ratio of about 50\%. The import penetration for agriculture is about $6.7 \%$ and the corresponding figure is about $5.5 \%$ for food. Possibly with the exception of petroleum, South Africa has very viable production capacity in the contested sectors and this has a direct bearing on economic outcomes of increased protection.

\subsubsection{The non calibrated parameters}

Results from CGE models are sensitive to the value of key supply and demand parameters. When dealing with policy changes of the nature introduced in this paper, it is important to use relevant elasticities, especially as far as (agricultural) trade elasticities are concerned. Our analysis distinguishes four sets of parameters that entered into the model, namely, the trade parameters (import substitution or Armington elasticities, and export supply and demand elasticities), the production technology parameters (substitution elasticities between factors), and the demand parameters for households (demand elasticity of income, and Frisch parameter) and the labour supply parameters (high skilled and low skilled unemployment rates).

For the short-run Armington elasticities, we use the estimates from Gibson (2003). The low-bound export supply and demand elasticities are obtained from Behar and Edwards (2004). The values of trade parameters are presented in Table 4.

Unemployment rates are drawn from the 2001 labour force survey report by Statistics South Africa (2001). To our knowledge, estimates for parameters in industries' production and households' demand are not available for South Africa. Therefore, our study borrows these values from the literature surveyed by Annabi et al. (2006), and analyses the sensitivity of the results with respect to these elasticities.

In general, results are not significantly affected by "reasonable" changes in these values.

Table 4

Trade elasticities

\begin{tabular}{|c|c|c|c|c|c|}
\hline \multirow[t]{2}{*}{ Industry } & \multirow[t]{2}{*}{$\begin{array}{l}\text { Armington } \\
\text { elasticity }\end{array}$} & \multicolumn{2}{|c|}{$\begin{array}{l}\text { Export supply } \\
\text { elasticity }\end{array}$} & \multicolumn{2}{|c|}{$\begin{array}{l}\text { Export demand } \\
\text { elasticity }\end{array}$} \\
\hline & & $\begin{array}{l}\text { Low } \\
\text { bound }\end{array}$ & $\begin{array}{l}\text { Upper } \\
\text { bound }\end{array}$ & $\begin{array}{l}\text { Low } \\
\text { bound }\end{array}$ & $\begin{array}{l}\text { Upper } \\
\text { bound }\end{array}$ \\
\hline Agriculture & 1.273 & 0.7 & 1.3 & 3 & 6 \\
\hline Coal & 2.771 & 0.7 & 1.3 & 3 & 6 \\
\hline Gold & 2.771 & 0.7 & 1.3 & 3 & 6 \\
\hline Other mining & 2.771 & 0.7 & 1.3 & 3 & 6 \\
\hline Food & 1.2535 & 0.7 & 1.3 & 3 & 6 \\
\hline Textiles & 1.262 & 0.7 & 1.3 & 3 & 6 \\
\hline Footwear & 2.04 & 0.7 & 1.3 & 3 & 6 \\
\hline Petroleum & 0.73 & 0.7 & 1.3 & 3 & 6 \\
\hline $\begin{array}{l}\text { Non metallic mineral } \\
\text { products }\end{array}$ & 0.655 & 0.7 & 1.3 & 3 & 6 \\
\hline Basic iron and steel & 0.447 & 0.7 & 1.3 & 3 & 6 \\
\hline Electrical machinery & 0.944 & 0.7 & 1.3 & 3 & 6 \\
\hline Radio & 0.441 & 0.7 & 1.3 & 3 & 6 \\
\hline Transport equipment & 0.932 & 0.7 & 1.3 & 3 & 6 \\
\hline Other manufacturing & 0.417 & 0.7 & 1.3 & 3 & 6 \\
\hline Electricity & 1.437 & 0.7 & 1.3 & 3 & 6 \\
\hline Water & 1.437 & 0.7 & 1.3 & 3 & 6 \\
\hline Construction & 1.28 & 0.7 & 1.3 & 3 & 6 \\
\hline Trade & 0.603 & 0.7 & 1.3 & 3 & 6 \\
\hline Hotels and restaurants & 0.42 & 0.7 & 1.3 & 3 & 6 \\
\hline Transport services & 0.861 & 0.7 & 1.3 & 3 & 6 \\
\hline Communications & 0.568 & 0.7 & 1.3 & 3 & 6 \\
\hline Financial intermediation & 0.616 & 0.7 & 1.3 & 3 & 6 \\
\hline Real estate & 1.066 & 0.7 & 1.3 & 3 & 6 \\
\hline Business activities & 1.066 & 0.7 & 1.3 & 3 & 6 \\
\hline General government & 1.153 & 0.7 & 1.3 & 3 & 6 \\
\hline Health and social work & 1.04 & 0.7 & 1.3 & 3 & 6 \\
\hline $\begin{array}{l}\text { Other activities } \\
\text { and services }\end{array}$ & 1.065 & 0.7 & 1.3 & 3 & 6 \\
\hline
\end{tabular}

Source: Gibson (2003) and Behar and Edwards (2004). 
Table 5

Macroeconomic effects (percent change)

\begin{tabular}{lc}
\hline & Change \\
\hline Price index & 0.01 \\
Imports & -0.01 \\
Exports & -0.01 \\
Unemployment rate* & 0 \\
Average wage & 0.01 \\
Return to capital & 0.01 \\
Consumer price index & 0.03 \\
Consumption & -0.01 \\
Saving & 0.04 \\
Investment average price & 0.01 \\
Investment & 0.06 \\
Gross domestic product & 0 \\
\hline
\end{tabular}

Source: compiled from 2000 SAM and simulation of doubling agricultural protection. Note: *change in point of percentage.

\subsubsection{The household survey data}

Data from the 2000 Household Income and Expenditure Survey (1ES) of South Africa and Labour Force Survey (LFS) were used for poverty analysis (Statistics South Africa, 2001, 2002). ${ }^{9}$ The surveys are nationally representative and have detailed information on household consumption patterns, income and household characteristics such as area, gender, number of persons and socio-economic characteristics.

There are numerous inconsistencies between the 1ES and the LFS (e.g. van der Berg et al., 2005; Pauw, 2005). Important differences between income and expenditures within the 1ES have been raised. For example, there has been substantial inflation in South Africa between 1995 and 2000, whereas the 2000 household survey data shows that nominal household per-capita incomes have decreased since 1995, the year of the previous household survey. The same does not apply to household expenditure levels, but a closer look of expenditure data shows that the withinhousehold subtotals of various expenditure categories do not add up to household overall totals. In the mean time, Statistics South Africa has changed unweighted sample composition since 1995, perhaps to reflect the true population of the country. The 2000 sample contains a much larger share of African households and a much smaller White households' share. The 1ES and the September LFS are based on the same sample of households interviewed but a lot of mismatches have been observed between the two databases as pointed out by Pauw (2005). Pauw (2005) has done an excellent job of cleaning and matching the 1ES and the LFS under the Provincial Decision-Making Enabling project. This work, made available to us, has been used to collect relevant information for decomposing the SAM built from the national accounts as well as the data for the microsimulation. For details on the procedure, the reader is referred to Pauw (2005).

\section{Simulation and results}

Our main simulation is designed in order to evaluate the impact of a possible DDA agreement whereby South Africa uses the room it has to manoeuvre within the SDT provisions to double tariffs on the agriculture sector. Government revenue is held constant through the introduction of an endogenous adjustment in indirect taxes or direct tax adjustment. ${ }^{10}$ Largely as a result of the low initial tariff rates on agriculture, the modelled doubling of tariffs will remain below any likely reduced bound levels. This is because the current WTO rules allow the country to charge a duty much higher than the country is presently charging on imported agricultural products. For instance, the WTO allows South Africa to charge up to $72 \%$ for wheat, $21 \%$ for durum, $41 \%$ for barley, and $50 \%$ for maize and yet the country currently charges only 3\% for these products (Vink and Tregurtha, 2003). The following sections trace in detail the impacts of the experiment as it channels through changes in macroeconomic variables, the sectoral allocation of production and inputs, factor prices, household income, consumer prices and welfare. The analysis is extended to assess the poverty and inequality implications of the scenario using the micro-simulation model. 


\subsection{Macroeconomic effects}

The increase of protection of agriculture products increases domestic prices for imported agricultural products which in turn reduces the imports of agricultural products. Due to the relatively elastic substitution between imported and locally produced agricultural products, ${ }^{11}$ imports of agriculture products fall by $0.6 \%$, respectively. The import bill increases as the fall in volumes is less significant than the increase in prices. With a fixed current account balance imposed on the model, the increase of the import bill puts downward pressure on the real exchange rate. Consequently, the real exchange rate decreases in order to re-equilibrate the current account balance. ${ }^{12}$ As the foreign average price is assumed exogenous and the exchange rate is also fixed, the domestic average price increase of $0.01 \%$ leads to a decline in the real exchange rate. Overall, imports and exports fall by $0.01 \%$ respectively (Table 5).

The increase of domestic prices induced by high agricultural prices increases input costs reduces business profits while leading to deterioration in consumers' purchasing power (Table 5). Consequently, real household consumption drops. Savings increase by $0.04 \%$ and investment by $0.06 \%$. The fall in real consumption offsets the increase in investment to leave gross domestic production unaffected, although there are important compositional shifts as we will see in the discussion below.

Table 6

Volume and price changes following a doubling of agricultural protection (indirect tax adjustment) (percent change)

\begin{tabular}{|c|c|c|c|c|c|c|c|}
\hline \multirow[t]{2}{*}{ Industry } & \multicolumn{4}{|c|}{ Volume change in } & \multicolumn{3}{|c|}{ Price change for } \\
\hline & Imports & Exports & Production & Domestic Demand & Imports & Domestic & Producer \\
\hline Agriculture & -0.612 & -0.107 & 0.080 & 0.102 & 0.632 & 0.102 & 0.089 \\
\hline Coal & 0.001 & 0.001 & 0.001 & 0.001 & 0.000 & 0.000 & 0.000 \\
\hline Gold & 0.000 & 0.001 & 0.001 & 0.000 & 0.000 & -0.001 & 0.000 \\
\hline Other mining & 0.001 & 0.001 & 0.001 & 0.001 & 0.000 & 0.000 & 0.000 \\
\hline Food & 0.035 & -0.056 & -0.015 & -0.012 & -0.005 & 0.034 & 0.037 \\
\hline Textiles & 0.007 & -0.001 & 0.003 & 0.004 & -0.002 & 0.001 & 0.003 \\
\hline Footwear & 0.007 & 0.004 & 0.006 & 0.006 & -0.001 & 0.000 & 0.001 \\
\hline Petroleum & 0.002 & 0.001 & 0.002 & 0.002 & -0.005 & -0.005 & 0.000 \\
\hline Other non-metallic mineral products & -0.001 & 0.000 & -0.001 & -0.001 & 0.000 & 0.000 & 0.000 \\
\hline Basic iron and steel & 0.000 & 0.001 & 0.001 & 0.001 & -0.001 & -0.002 & -0.001 \\
\hline Electrical machinery & 0.000 & 0.002 & 0.001 & 0.001 & -0.001 & -0.002 & -0.001 \\
\hline Radio & 0.002 & 0.003 & 0.003 & 0.003 & -0.003 & -0.003 & -0.001 \\
\hline Transport equipment & 0.001 & 0.003 & 0.002 & 0.002 & -0.002 & -0.003 & -0.001 \\
\hline Other manufacturing & 0.007 & -0.009 & -0.003 & -0.001 & -0.001 & 0.006 & 0.006 \\
\hline Electricity & 0.004 & 0.000 & 0.002 & 0.002 & -0.001 & 0.000 & 0.001 \\
\hline Water & 0.003 & 0.000 & 0.001 & 0.001 & -0.001 & 0.001 & 0.001 \\
\hline Construction & -0.001 & 0.001 & 0.000 & 0.000 & -0.002 & -0.003 & -0.001 \\
\hline Trade & -0.002 & -0.002 & -0.002 & -0.002 & 0.000 & 0.000 & 0.000 \\
\hline Hotels and restaurants & 0.011 & -0.011 & -0.002 & 0.000 & -0.002 & 0.007 & 0.008 \\
\hline Transport services & 0.001 & 0.002 & 0.002 & 0.002 & 0.001 & 0.000 & -0.001 \\
\hline Communications & 0.001 & 0.001 & 0.001 & 0.001 & 0.000 & -0.001 & 0.000 \\
\hline Financial intermediation & 0.002 & 0.001 & 0.001 & 0.002 & -0.001 & 0.000 & 0.001 \\
\hline Real estate & 0.006 & -0.003 & 0.002 & 0.002 & -0.002 & 0.001 & 0.003 \\
\hline Business activities & 0.000 & -0.001 & 0.000 & 0.000 & -0.001 & 0.000 & 0.000 \\
\hline General government & 0.000 & 0.000 & 0.000 & 0.000 & 0.000 & 0.006 & 0.006 \\
\hline Health and social work & 0.005 & 0.001 & 0.004 & 0.004 & -0.002 & -0.001 & 0.001 \\
\hline Other activities and services & 0.003 & 0.001 & 0.003 & 0.003 & -0.002 & -0.001 & 0.001 \\
\hline All* & -0.008 & -0.008 & -0.001 & 0.000 & 0.009 & 0.007 & 0.007 \\
\hline
\end{tabular}

Source: compiled from 2000 SAM and simulation of doubling agricultural protection.

Note: *average variation for volumes - Laspeyres index variation for prices.

\subsection{Trade and production effects}

Table 6 reports the sectoral results of doubling agricultural protection with government revenue balanced by adjustment of indirect taxes. The immediate impact of the simulation is an increase in the domestic price of imports by $0.01 \%$, driven mainly an increase of agricultural import prices of $0.632 \%$. Because the adjustment mechanism is through indirect tax, the changes in domestic sectoral import prices extends beyond the agriculture sector prices to other import prices which decline, thereby dampening substantially the negative impact on import prices induced by increased agricultural protection. The overall increase of import prices leads local consumers to demand less imports. As a result, imports fall by $0.01 \%$, which is roughly the same proportion as the increase in sector tariff rates.

With a fixed current account balance, the fall in imports leads to a $0.01 \%$ exchange rate appreciation, which partially offsets the rise in import prices in the agriculture sector and leads to a decrease in the domestic price of imports in some other sectors (see Table 6). As would be expected, the fall in imports is beneficial to domestic competitors, who experience a small increase in the volume and price of their sales on the local market. Given the 
imperfect substitution between local and imported goods (CES), as well as the relatively small initial import intensities (imports/domestic consumption), the changes here are proportionally much smaller than the variations in import volumes.

Most of the industries with high agricultural input intensities relative to value added and a high share of agriculture in input cost witness a substantial fall in their output as compared to other industries. The incidence is most significant on the output of food, and other manufacturing (consisting of wood, paper, tyres, and other rubber). They are joined by a small group of non agriculture input-intensive industries such as trade, hotels and restaurants that account for a large share of food demand. However, a small number of high agriculture input-intensive industries such as textiles do not experience important reductions in their output. The textiles industry benefits from the income inelasticity of household demand which means that households' demand for textiles does not fall by as much as the price increases. The other services, in particular government services benefit from the real appreciation induced by the increased protection. The increased agricultural protection benefits marginally industries in the heavy manufacturing sector (such as basic iron and steel, electrical machinery, transport equipment), nontradable capital sectors (electricity and water) and mining sectors (coal, gold, other mining).

Table 7

Factor effects (indirect tax adjustment)

\begin{tabular}{|c|c|c|c|c|c|c|c|c|c|}
\hline \multirow[t]{2}{*}{ Industry } & \multicolumn{2}{|l|}{ Change in } & \multicolumn{4}{|l|}{ Shares } & \multicolumn{3}{|l|}{ Change in } \\
\hline & Price of value added & Value added & LDi/VAi & $\mathrm{KD} i / \mathrm{VAi}$ & wLDi/wLD & $\mathrm{rKD} i / \mathrm{rKD}$ & wi & ri & LDi \\
\hline Agriculture & 0.1719 & 0.079 & 50.1101 & 49.89 & 2.6959 & 5.4329 & 0.1719 & 0.1719 & 0.08 \\
\hline Coal & 0.0006 & 0.001 & 41.4094 & 58.591 & 0.8542 & 2.4463 & -0.0003 & 0.0013 & 0.0025 \\
\hline Gold & 0 & 0.0011 & 68.676 & 31.324 & 2.5085 & 2.3159 & -0.0003 & 0.0007 & 0.0015 \\
\hline Other mining & 0.0005 & 0.001 & 42.9762 & 57.024 & 1.6793 & 4.5103 & -0.0003 & 0.0012 & 0.0023 \\
\hline Food & -0.01 & -0.0151 & 51.0298 & 48.97 & 2.6129 & 5.0753 & -0.0003 & -0.02 & -0.0295 \\
\hline Textiles & 0 & 0.0031 & 86.7195 & 13.281 & 1.3009 & 0.4033 & -0.0003 & 0.0021 & 0.0036 \\
\hline Footwear & 0.0018 & 0.0061 & 65.8297 & 34.17 & 0.134 & 0.1408 & -0.0003 & 0.0058 & 0.0093 \\
\hline Petroleum & 0.0009 & 0.0018 & 48.8189 & 51.181 & 2.9832 & 6.3305 & -0.0003 & 0.0022 & 0.0038 \\
\hline Other non-metallic mineral products & -0.0007 & -0.0007 & 55.0711 & 44.929 & 0.5916 & 0.9769 & -0.0003 & -0.0011 & -0.0012 \\
\hline Basic iron and steel & 0 & 0.0009 & 64.8565 & 35.144 & 4.1853 & 4.5905 & -0.0003 & 0.0006 & 0.0014 \\
\hline Electrical machinery & 0.0004 & 0.0011 & 52.5891 & 47.411 & 0.4586 & 0.8369 & -0.0003 & 0.0011 & 0.0022 \\
\hline Radio & 0.0001 & 0.0026 & 79.9405 & 20.06 & 0.3206 & 0.1628 & -0.0003 & 0.0018 & 0.0032 \\
\hline Transport equipment & 0.0002 & 0.0021 & 72.1357 & 27.864 & 1.492 & 1.1665 & -0.0003 & 0.0016 & 0.0029 \\
\hline Other manufacturing & -0.0017 & -0.0026 & 56.0282 & 43.972 & 2.6759 & 4.2509 & -0.0003 & -0.0035 & -0.0047 \\
\hline Electricity & 0.0022 & 0.002 & 35.0037 & 64.996 & 1.4748 & 5.5431 & -0.0003 & 0.0035 & 0.0057 \\
\hline Water & 0.0026 & 0.0011 & 20.063 & 79.937 & 0.1561 & 1.2593 & -0.0003 & 0.0033 & 0.0055 \\
\hline Construction & -0.0003 & 0.0001 & 76.6643 & 23.336 & 3.683 & 2.2691 & -0.0003 & -0.0003 & 0.0001 \\
\hline Trade & -0.0004 & -0.0019 & 92.6706 & 7.3294 & 17.0582 & 2.7308 & -0.0003 & -0.0017 & -0.0021 \\
\hline Hotels and restaurants & -0.0016 & -0.0015 & 45.366 & 54.634 & 1.4323 & 3.4913 & -0.0003 & -0.0026 & -0.0034 \\
\hline Transport services & 0.0002 & 0.0018 & 70.2133 & 29.787 & 5.469 & 4.6962 & -0.0003 & 0.0014 & 0.0025 \\
\hline Communications & 0 & 0.0013 & 73.5399 & 26.46 & 3.4835 & 2.537 & -0.0003 & 0.0008 & 0.0018 \\
\hline Financial intermediation & 0.0006 & 0.0014 & 51.1163 & 48.884 & 6.6567 & 12.8854 & -0.0003 & 0.0015 & 0.0028 \\
\hline Real estate & 0.0046 & 0.0019 & 20.5699 & 79.43 & 2.0446 & 15.9807 & -0.0003 & 0.0059 & 0.0093 \\
\hline Business activities & -0.0004 & -0.0002 & 92.5869 & 7.4131 & 3.9608 & 0.6419 & -0.0003 & -0.0005 & -0.0003 \\
\hline General government & 0.0075 & 0.0002 & 88.9493 & 11.051 & 23.0694 & 5.8012 & 0.0075 & 0.0075 & 0.0003 \\
\hline Health and social work & 0.0021 & 0.0037 & 50.19 & 49.81 & 1.3826 & 2.7773 & -0.0003 & 0.0046 & 0.0074 \\
\hline Other activities and services & -0.0002 & 0.0025 & 93.8547 & 6.1453 & 5.6362 & 0.747 & -0.0003 & 0.0014 & 0.0026 \\
\hline All & 0.0075 & & 66.9325 & 33.068 & 100 & 100 & & & \\
\hline
\end{tabular}

Source: compiled from 2000 SAM and simulation of doubling agricultural protection.

Note: $i=$ sectors; $\mathrm{LD}=$ labour demand; $\mathrm{KD}=$ capital demand; $w=$ wage rate; $r=$ return on capital; VA=value added.

Table 8

Factor price effects (indirect tax adjustment)

\begin{tabular}{|c|c|c|c|c|c|c|c|c|c|c|}
\hline & \multicolumn{5}{|l|}{ Share in } & \multicolumn{5}{|c|}{ Change in } \\
\hline & Wagr & Wnag & Wgse & $r$ & Other & Wagr & Wnag & Wgse & $r$ & Other \\
\hline African & 3.0981 & 52.0815 & 18.002 & 9.4049 & 17.4139 & 0.0053 & -0.0002 & 0.0014 & 0.0009 & 0.0013 \\
\hline Coloured & 3.1851 & 62.9435 & 20.992 & 7.251 & 5.6283 & 0.0055 & -0.0002 & 0.0016 & 0.0007 & 0.0004 \\
\hline Asian & 0.4567 & 72.2394 & 12.818 & 12.002 & 2.4842 & 0.0008 & -0.0002 & 0.001 & 0.0012 & 0.0002 \\
\hline White & 1.1812 & 64.6357 & 18.967 & 13.764 & 1.4512 & 0.002 & -0.0002 & 0.0014 & 0.0013 & 0.0001 \\
\hline
\end{tabular}

Source: compiled from 2000 SAM and simulation of doubling agricultural protection.

Note: Wagr=agricultural wage; Wnag=non agriculture wage; Wgse=services wage; $r=$ return on capital. 


\subsection{Factor effects}

In this section we discuss how the trade and output effects just discussed then end up influencing factor prices and employment. Factor prices and employment are both critical when analyzing welfare and poverty effects. The key driving mechanisms of factor input prices are value added prices because they are net of intermediate input costs. Output prices, on the other hand, influence factor demands. According to Table 7, value added prices rise the most for agriculture as would be expected. The contrary is true for the sectors with a low content of agricultural inputs. The rest of this table shows the shares of total income that each factor derives from each of the sectors as well as the wage and capital bill (Table 7).

To explain wage impacts, we refer throughout to the value added price variations and factor intensities in Table 7. Whereas public sector employment and wage rates are assumed fixed, private sector workers are assumed to be mobile between sectors with wage rates that equalize across all private sectors. We note substantial differences in private sector wage rate changes according to the location and ethnicity of the workers (Table 8).

Wages generally grow for services and agriculture while they fall for the nonagricultural sectors. ${ }^{13}$ Indeed, agricultural wage rates grow by far more than those in services and other non agriculture sectors (which actually experience a decline). Because African and Coloured workers have relatively higher shares in agricultural wages (Table 8), their wage rates generally evolve more favorably than White and Asian wage rates. Asian workers are penalized by their greater participation in non-agriculture, for which value added prices fall (Table 8).

Capital is assumed to be sector-specific because of the short-term horizon of our analysis. As a result, variations in the rates of returns to capital closely follow changes in the value-added prices of their respective sectors. These rates fall most in the sectors that are highly dependent on agriculture for their inputs (Table 7).

Table 9

Change in consumer prices (indirect tax adjustment)

\begin{tabular}{|c|c|c|c|c|c|c|c|c|}
\hline \multirow[t]{2}{*}{ Sectors } & \multicolumn{4}{|c|}{ Change in prices and tax rate } & \multicolumn{4}{|c|}{ Consumption share } \\
\hline & $\mathrm{dtx}$ & $\mathrm{dPM} i$ & $\mathrm{dPD} i$ & $\mathrm{dPC} i$ & African & Coloured & Asian & White \\
\hline Agriculture & -0.04 & 0.6319 & 0.1016 & 0.1377 & 1.922 & 0.4535 & 0.9018 & 4.5584 \\
\hline Coal & -0.04 & -0.0001 & -0.0001 & -0.0001 & 0.0765 & 0.0155 & 0.0054 & 0.0064 \\
\hline Gold & -0.04 & 0 & -0.001 & -0.001 & 0 & 0 & 0 & 0 \\
\hline Other mining & -0.04 & 0 & 0 & 0 & 0 & 0 & 0 & 0 \\
\hline Food & -0.04 & -0.0045 & 0.0342 & 0.0316 & 37.665 & 41.2358 & 28.332 & 18.7262 \\
\hline Textiles & -0.04 & -0.002 & 0.0011 & 0.0007 & 6.8337 & 6.5476 & 5.8091 & 3.743 \\
\hline Footwear & -0.04 & -0.0012 & -0.0003 & -0.0005 & 1.9918 & 1.7365 & 1.3719 & 0.7198 \\
\hline Petroleum & -0.04 & -0.0048 & -0.0046 & -0.0046 & 6.5713 & 6.7 & 9.6632 & 10.5771 \\
\hline Other non-metallic mineral products & -0.04 & 0.0003 & -0.0001 & -0.0001 & 0.0916 & 0.0534 & 0.0656 & 0.0684 \\
\hline Basic iron and steel & -0.04 & -0.0012 & -0.0019 & -0.0016 & 1.23 & 1.4357 & 1.5925 & 1.3522 \\
\hline Electrical machinery & -0.04 & -0.0014 & -0.002 & -0.0018 & 0.179 & 0.1599 & 0.3063 & 0.2453 \\
\hline Radio & -0.04 & -0.0028 & -0.0034 & -0.0031 & 1.8322 & 1.9296 & 2.0155 & 2.043 \\
\hline Transport equipment & -0.04 & -0.0017 & -0.0027 & -0.0024 & 1.6246 & 2.7965 & 5.8663 & 6.0636 \\
\hline Other manufacturing & -0.04 & -0.0007 & 0.0058 & 0.0048 & 6.1811 & 4.2137 & 4.5654 & 3.1174 \\
\hline Electricity & -0.04 & -0.001 & 0.0004 & 0.0004 & 2.4855 & 2.8186 & 1.7093 & 1.4501 \\
\hline Water & -0.04 & -0.0006 & 0.0006 & 0.0006 & 0.274 & 0.5281 & 0.5 & 0.3763 \\
\hline Construction & -0.04 & -0.0017 & -0.0027 & -0.0027 & 0 & 0 & 0 & 0 \\
\hline Trade & -0.04 & -0.0001 & -0.0001 & -0.0001 & 0.8038 & 0.7411 & 1.7441 & 1.9171 \\
\hline Hotels and restaurants & -0.04 & -0.0016 & 0.0073 & 0.0063 & 2.2501 & 1.7262 & 2.5895 & 3.3877 \\
\hline Transport services & -0.04 & 0.0005 & -0.0001 & 0 & 7.9331 & 5.5959 & 4.6166 & 2.7033 \\
\hline Communications & -0.04 & -0.0004 & -0.0007 & -0.0007 & 1.5978 & 2.7726 & 4.117 & 3.5581 \\
\hline Financial intermediation & -0.04 & -0.0008 & -0.0003 & -0.0003 & 3.9865 & 4.9598 & 6.0916 & 10.4184 \\
\hline Real estate & -0.04 & -0.002 & 0.0014 & 0.0014 & 5.0256 & 6.2526 & 7.6794 & 13.1341 \\
\hline Business activities & -0.04 & -0.0005 & -0.0002 & -0.0002 & 0.223 & 0.3387 & 0.353 & 0.674 \\
\hline General government & -0.04 & 0 & 0.0059 & 0.0061 & 0.1791 & 0.1805 & 0.6444 & 0.3274 \\
\hline Health and social work & -0.04 & -0.0023 & -0.001 & -0.001 & 3.3296 & 3.4029 & 4.2266 & 5.8425 \\
\hline Other activities and services & -0.04 & -0.0018 & -0.0012 & -0.0012 & 5.7136 & 3.4052 & 5.2337 & 4.9902 \\
\hline ALL & 0 & 0.0092 & 0.0067 & 0.007 & 100 & 100 & 100 & 100 \\
\hline Change in household consumer price & & & & & 0.0146 & 0.0135 & 0.0099 & 0.0119 \\
\hline
\end{tabular}

Source: compiled from 2000 SAM and simulation of doubling agricultural protection.

Note: $\mathrm{dtxi}=$ change in indirect tax; $\mathrm{dPM} i=$ change in domestic import price in sector $i$;PD $i=$ change in sectoral price of the domestic good; $\mathrm{dPC} i=\mathrm{change}$ in price of the composite good

\subsection{Income, consumption and welfare effects}

Wages are the principal source of income in South Africa, followed by various forms of in-transfers (from other households, government, etc.). There are substantial differences between urban and rural household groups. Factor price changes affect the incomes of households differently according to their factor (labour and capital) endowments. We have seen that the distributional impact on capital returns is small while that from agricultural wages is relatively substantial. Therefore, we would expect low distributional effects from capital income changes and quite high distributional effects from agricultural wages. Overall, income changes for the aggregate household are very small at $0.007 \%$ (Table 9 ). However, this masks substantial differences across households. On average, incomes increase by 0.008 for African and Coloured households as a consequence of rising agricultural 
wage rates and transfers (Africans), while they only increase by 0.005 and $0.003 \%$ for White and Asian households (Table 10) (most of their income comes from the declining non agriculture wages and capital which experiences very small increases). However, incomes decrease in real terms for White and Asian households after account is taken of the $0.007 \%$ increase of the economy-wide price index. Disposable incomes evolve in a similar pattern to nominal incomes (Table 9).

Table 10

Change in welfare (indirect tax adjustment)

\begin{tabular}{lccrrr}
\hline & African & Coloured & \multicolumn{1}{c}{ Asian } & \multicolumn{1}{l}{ White } & \multicolumn{1}{l}{ All } \\
\hline Change in nominal income & 0.0087 & 0.008 & 0.0028 & 0.0047 & 0.0066 \\
Initial direct tax rate & 11.7798 & 9.671 & 14.3139 & 14.2509 & \\
Change in net nominal income & 0.0087 & 0.008 & 0.0028 & 0.0047 & 0.0067 \\
Share transfers out & 0.9933 & 28.415 & 4.9827 & 2.5868 & 4.3537 \\
Change in disposal income & 0.0087 & 0.0082 & 0.0026 & 0.0046 & 0.0066 \\
Propensity to save & 1.195 & 0.3937 & 0.4394 & 0.6913 & 0.8887 \\
Change in total consumption & 0.0171 & 0.0109 & 0.0056 & 0.0094 & 0.0128 \\
Change in consumer price index & 0.0146 & 0.0135 & 0.0099 & 0.0119 & 0.007 \\
Equivalent variation/nominal & 0.0022 & -0.0016 & -0.0035 & -0.0021 & -0.0003 \\
income & & & & & \\
\hline
\end{tabular}

ər than the increase in all the ;rows at the same rate. The led price.

Source: compiled from 2000 SAM and simulation of doubling agricultural protection.

\section{Table 11}

Poverty and inequality indexes (in \%)

\begin{tabular}{|c|c|c|c|c|c|c|}
\hline & \multicolumn{3}{|c|}{ Initial values } & \multicolumn{3}{|c|}{ Variation } \\
\hline & P0 & P1 & P2 & $\overline{\mathrm{P} 0}$ & P1 & $\mathrm{P} 2$ \\
\hline South Africa & 53.0 & 25.3 & 15.0 & 0.003 & 0.002 & 0.01 \\
\hline \multicolumn{7}{|l|}{ Residential area } \\
\hline Urban & 42.4 & 18.4 & 10.2 & 0.02 & 0.01 & 0.01 \\
\hline Rural & 68.3 & 35.4 & 22.1 & 0.00 & 0.00 & 0.00 \\
\hline \multicolumn{7}{|l|}{ Population group } \\
\hline African household & 61.0 & 29.5 & 17.6 & -0.001 & 0.00 & 0.00 \\
\hline Colored household & 36.2 & 14.7 & 7.8 & 0.000 & 0.000 & 0.000 \\
\hline Asian household & 6.4 & 2.3 & 0.8 & 0.001 & 0.001 & 0.000 \\
\hline White household & 0.1 & 0.0 & 0.0 & 0.01 & 0.00 & 0.00 \\
\hline
\end{tabular}

Source: compiled from 2000 IES and LFS and simulation of doubling agricultural protection (indirect tax adjustment).

Note: $\mathrm{P} 0=$ poverty headcount; $\mathrm{P} 1=$ poverty gap; and $\mathrm{P} 2=$ poverty severity.

Increased agricultural protection also influences household welfare through changing consumer prices. Each household is affected differently by consumer price increases according to its consumption patterns. Whites consume disproportionately more of the agriculture good while Coloured households consume disproportionately more food. Table 10 shows that even after adjusting for the tax reduction to compensate import tariff increases, consumer prices increase by $0.007 \%$ due to increases in agriculture and food prices (Table 10 ). In this respect, we note that consumption prices increase for all households. In real terms, consumption prices decrease only for African households as the economy-wide price index increases by more. In contrast, all other households experience real consumption price increases.

The net effect of these nominal income and price changes is summarized by equivalent variation, which suggests that the overall impact on welfare is mildly negative $(-0.0003 \%)$ as the percent increase in nominal consumption is insufficient to reverse the negative effects of consumer price increases (Table 10). African 
households have the largest positive welfare effect due to the large increase in nominal consumption relative to the increase in the consumer price index. Finally, all other population groups experience declining welfare, with the worst affected being the Asian households.

\subsection{Poverty and inequality effects}

Up to this stage, the CGE model has given us post simulation impacts on consumption, prices and welfare but we have not yet exploited individual variation at the household level. After applying the CGE results to the household survey data using the procedures described earlier in the methodology section, standard consumptionbased poverty and inequality indicators are reported in Table 11. According to Table 11, 53\% of South Africans were poor in 2000 according to the lower bound 'cost of basic needs approach' poverty line of 3864 South Africa rands per year in 2000 prices. The poverty gap was 25\% while the poverty gap squared (severity) was 15\%. According to Table 11, it is clear that poverty affects mainly African households and to some extent Coloured households where 61 and $36.2 \%$ respectively are classified as poor. Poverty is very low among Asian households and virtually non existent amongst White households at $0.1 \%$.

The impact of increased agricultural protection with indirect tax adjustment on poverty is captured by changes in the poverty indices reported in the last column of Table 11. The changes in poverty are largely driven by changes in the consumer price index and changes in household consumption. Using the percent change in average head-count index of poverty measure, the results suggest that the impacts on poverty reduction are very small. Urban households shoulder the highest poverty burden. This is largely because of their higher dependence on food consumption (whose price has risen due to protection of agriculture) and lower participation in agriculture labour markets. Poverty levels for rural households remain virtually unchanged. Poverty increases slightly more among Asian households, followed by White and then Coloured households. While the increase in poverty for Asian and White households is due to declining income levels, the increase in poverty levels for Coloured households can directly be traced back to its higher consumption share of foodstuffs. African households are the clear winners as they experience small declines in poverty.

\section{Conclusion}

Recently, there have been increasing calls for developing countries to use provisions for SDT to increase agricultural protection. This paper explores the effects that a higher tariff on agriculture imports could have in South Africa. The paper has argued that although this question may be hypothetical in the sense that it is not based on the submissions of the Contracting Parties to the WTO Secretariat, it is of broader relevance to developing countries that may be contemplating the use of SDT provisions so as to better achieve their developmental objectives from multilateral trade reforms. To address the question, the paper has used a top down CGE microsimulation model for South Africa. Policy makers should be aware of the production, labor, income, welfare and poverty implications of increased agricultural protection in the context of their negotiations with the WTO and other bilateral FTAs.

The model predicts that increases of protection of agriculture products have a negligible impact on gross domestic production. Overall, imports and exports fall while real household consumption drops. The overall increase of import prices leads local consumers to demand less imports. At the sectoral level, sectors are impacted according to the share of agriculture in total inputs. Wage rates generally evolve more favourably for African and Coloured workers because of their relatively higher shares in agricultural wages. Overall, income changes for the aggregate household are very small and so are the impacts on poverty. Poverty increases slightly more among Asian households, followed by White and then Coloured households. African households experience reductions in poverty.

There are some caveats to be aware of when using the results of this study. First, the SAM used has only single agricultural sector. This brings with it some inherent biases especially if there are significant differences in production behaviour within disaggregated agriculture sub-sectors. Second, the paper has used applied tariff rates and this may introduce aggregation problems. Third and finally, it should be noted that a multilateral Doha Development Agenda agreement on agriculture will likely include removal of export subsidies, tariff reductions and some domestic support reductions, for many other countries. These will impact on export and import prices faced by South Africa and will by themselves have some household and welfare effects. The modelled scenario in this paper assumes that other countries make no policy adjustments, that is, the small country assumption is maintained.

\section{Acknowledgements}

Ramos Mabugu thanks the Poverty and Economic Policy (PEP) Research Network for financial and technical support. We thank Kalie Pauw for discussion and sharing his work on household surveys with us. We are extremely grateful for comments received from anonymous reviewers. All opinions should be ascribed to the authors, rather than to the Financial and Fiscal Commission or the University of Pretoria. 


\section{References}

Annabi, N., Decaluwe, B., Cockburn, J., 2006. Functional forms and parameterization of CGE models. PEP, MPIA Working Paper 2006-04.

Behar, A., Edwards, L, 2004. Estimating elasticities of demand and supply for South Africa manufactured exports using a vector error correction model. The Centre for the Study of Economies, Working Paper.

Decaluwe, B., Martens, A., Savard, L, 2001. La politique economique du developpement et les modeles d'equilibre general calculable. Montreal University Press.

Diaz-Bonilla, E., Diao, $X$., Robinson, R., 2003. Thinking inside the boxes: protection and investments in the development and food security boxes. Contributed paper presented at the International Conference: Agricultural Policy Reform and the WTO: Where are we heading?

Capri, Italy. Essama-Nssah, B., Go, D., Kearney, M., Korman, V., Robinson, S., Thierfelder, K., 2007. Economywide and distributional impacts of an oil price shock on the South Africa Economy. Policy Research Working Paper 4354, Washington D.C The World Bank.

Fofana, I., Cockburn, J., Decaluwe, B., Mabugu, R., Chitiga, M., 2007. A Gender-focused macro-micro analysis of the poverty impacts of trade liberalisation in South Africa. Research on Economic Inequality 15, 269-305.

Foster, J.E., Greer, J., Thorbecke, E., 1984. A class of decomposable poverty measures. Econometrica 52, 761-776.

Gibson, K.L., 2003. Armington elasticities for South Africa: long- and short-run industry level estimates. Trade and Industrial Policy Strategies, Worldng Paper 12-2003.

Herault, N., 2006. Building and linking a microsimulation model to a CGE model for South Africa. South Africa Journal of Economics 74 (1), 34-58.

Hoogeveen, J.G., Ozler, B., 2004. Not Separate, Not Equal Poverty and Inequality in Post-Apartheid South Africa, World Bank, 1818 H Street NW, Washington DC, 20433, USA

Kandiero, T, Kirsten, J.F., Ngqangweni, S., 2004. Protection regimes in SADC: stylized facts. Paper prepared for the Southern Africa Trade Research Network (SATRN), April 19-23.

Kirsten, J.F., Vink, N., 2002. Pricing behaviour in the South Africa food and agricultural sector. A Report to the National Treasury, South Africa.

Konandreas, P., 2003. The state of play in the WTO negotiations on agriculture and implications of different modalities. Paper prepared for the South Africaern Africa Trade Research Network (SATRN), July 2-3.

Mabugu, R., Chitiga, M.R., 2007. Poverty and inequality impacts of trade policy reforms in South Africa. PEP Network Worldng Paper, University of Laval, Canada.

McDonald, S., Punt, C, 2005. General equilibrium modelling in South Africa: what the future holds. Agrekon 44 60-97. Organisation for Economic Co-operation and Development OECD Review of Agricultural Policies: South Africa. Available at http://www.sourceoecd.org/agriculture/ 9264036792: 2006.

Pauw, K., 2005. Creating a 2000 IES-LFS database in Stata. Technical Paper 2005:1,Provincial Decision-Making Enabling (PROVIDE), South Africa.

Rangasamy, L, Harmse, C, 2003. Revisiting the extent of trade liberalisation in the 1990s. South African Journal of Economics 70 '(4), 705-728.

Simians, C. A critical assessment of the 1995 and 2000 income and expenditure surveys as sources of information on incomes. Unpublished manuscript, Witwatersrand University: 2003.

Statistics South Africa, 2001. Labour force survey February 2001 Statistical release P0210. Pretoria, South Africa.

Statistics South Africa, 2002. Earning and spending in South Africa. Selected findings and comparisons from the income and expenditure surveys of October 1995 and October 2000. Pretoria, South Africa.

Thurlow, J., van Seventer, D., 2002. A standard computable general equilibrium for South Africa. International Food Policy Research Institute, Trade and Macroeconomics Division Worldng Paper No. 100, Washington D.C

Van der Berg, S., Burger, R, Burger, R, Louw, M., Yu, D., 2005. Trends in poverty and inequality since the political transition. Stellenbosch Economic Working Papers: 1 /2005. University of Stellenbosch, South Africa.

Vink, N., Tregurtha, N., 2003. Domestic agricultural support in SADC: The impact on regional trade and the consequences for development. Department of Agricultural Economics, University of Stellenbosch, South Africa.

Woolard, I., Wilson, R, 2004. Developing a national skills forecasting tool for South Africa. Paper commissioned by EEPR Human Sciences Research Council. 


\section{Notes}

van der Berg et al. (2005) have recently presented evidence showing that that poverty has sharply declined in the last few years largely as a result of increases in social grants, which have significantly alleviated poverty. However, they agree that poverty levels are stilf very high.

${ }^{2}$ As pointed out in Rangasamy and Harmse (2003), GEIS was also phased out as a result of a policy shift that entailed tariff liberalization as a means of reducing the anti-export bias in the economy

${ }^{3}$ Other agro-food have ad valorem tariff rates as follows: soybeans (8-10\%), sunflower (set at 3.5\%), fruits (7.3\%), vegetables (10.6\%), meat products (up to 50\%), meat and edible meat offal (up to $40 \%$ ), dairy products (subject to specific tariff above average agricultural tariff level), live animals (duty free), wool and fine or coarse animal hair ( 0 tariff).

${ }^{4}$ To our knowledge, there is no peer reviewed published work yet that uses CGE microsimulation analysis on agriculture for South Africa. However, we are aware of ongoing work to build microsimulation CGE models for South Africa (Essama-Nssah et al., 2007; Fofana et al., 2007; Mabugu and Chitiga, 2007; Herault, 2006). The focus of these studies, however, is not on agricultural trade.

${ }^{5}$ We have limited the skill disaggregation to two categories for each ethnic group for simplicity, as further decomposition will likely not affect substantially our (macro and meso) results. However, we believe that the level of disaggregation of factors, in particular labor, will have strong distributional impacts among households when the latter are more decomposed (in the microsimulation) but that these are well taken care of by changes in consumption levels and consumer price indexes obtained from the macro CGE model. Therefore, we are expecting to have picked up most of this distributional impact in this manner

${ }^{6}$ We first decided to use a wage curve for both high skilled and low skilled labour markets, which means a flexible wage and unemployment rates. We were uncomfortable with the presence of unemployment amongst high skilled labour as this contradicts the available empirical evidence.

${ }^{7}$ Some examples are FGT index, Watts's index, and Clark, Hemming and Ulph (CHU) index.

${ }^{8}$ There is a SAM built under the PROVIDE Project SAM for South Africa in 2000 which has 3 agricultural and 11 food commodities and 9 agricultural and 11 food activities. Unfortunately this SAM is not in the public domain and hence could not be used.

${ }^{9}$ It should be noted that there is an active literature discussing the merits and demerits of this household survey (see for example, Hoogeveen and Ozler, 2004). The main criticism center on the perceived inadequacies of the sampling weights used, the lack of information required to impute comparable values on home produced goods and the lack of relevant quantities data to compute 'unit values' and price data to compute food prices at the community level. The latter two criticisms are largely irrelevant for this work since the CGE model is used to generate price and quantities information while Simkins (2003) has demonstrated that the 2000 sampling weights are not as unreliable as first feared.

10 To reduce requirements for space and also because the results are largely similar, the discussion in the text will concentrate on the indirect tax adjustment scenario. Results of the direct tax adjustment scenario can be made available upon request from the interested reader.

${ }^{11}$ It is relatively easy to substitute imported agricultural products by locally produced agricultural products in the aggregate. The value of the elasticity of substitution is set at 1.273 and is among the highest values estimated for the Armington elasticity in South Africa by Gibson (2003). Table 4 gives more details on the elasticity values used in the study.

12 The real exchange rate is defined as the ratio of foreign average price (converted in local currency by the exchange rate) to domestic average price.

${ }^{13}$ It is important to note that the wage rate in government increases by $0.0075 \%$, which is much higher than the increase in all the other non agricultural sectors. This is because it is indexed to its value added price and hence grows at the same rate. The economy wide wage rate increases by $0.0061 \%$, which is lower than the increase in overall value added price. 